\title{
at aMs headquarters
}

Exccutive Director Spengler left Boston on 1 October to attend the Second Conference on Numerical Prediction in Monterey, Calif. He returned on the 4th.

On 10 October the Publications Committee met at Headquarters. Attending the meeting were: Glenn R. Hilst, Commissioner; Members at Large, William H. Hooke, Owen M. Phillips, and Edward S. Epstein; S. I. Rasool, editor, JournaI. of the Atmospheric Sciences; James R. Mahoney, newly. appointed editor, Journal of Applied Meteorology; Robert O. Reid, editor, Journal of Physical Oceanography; Malcom Rigby, editor, METEOROLOGICAL AND GEOASTROPHYSICAL Abstracts; Eugene W. Bierly, editor, Meteorological MonoGRAPHS; Chester W. Newton, newly-appointed AMS editor of the Monthly Weather Review; Harold A. Corzine, current editor, Monthly Weather Review (NOAA); James E. Caskey, Jr., Director, Environmental Science Information Center (NOAA); John Spengler, assistant editor, Journal of Applied Meteorology; Harriet R. Newton, assistant editor, Monthly Weather Review; Donald Sherick, Lancaster Press; Kenneth C. Spengler, editor, Bulletin of the American Meteorological Society; and Richard Belknap, Consultant. AMS staff members in attendance were: John Gerhardt, technical editor, AMS journals, Miles F. Harris, technical editor, Bulletin; Evelyn Mazur, meetings editor, Bulletin; Mari Okie, news editor, Bulletin; and Mary F. Buckley and Lilly G. Albo, editorial assistants, AMS publications.

The Executive Committee also met on the afternoon of the 10th. They were joined by members of the Council at a reception held at Headquarters in the evening. The Council met on the 11th and 12th. Attending were: President William W. Kellogg; President-Elect David S. Johnson, Past Presidents Richard J. Reed and Eugene Bollay; Secretary of the Council, Charles L. Hosler; Councilors, William J. Kotsch, Silvio G. Simplicio, Warren S. Wooster, David Atlas, Robert D. Fletcher, Max A. Kohler, Patrick D. McTaggartCowan, Frederick G. Shuman, William H. Best, Jr., William H. Klein, Richard S. Lindzen, and Jerome Namias; Commissioners, Louis J. Battan, Scientific and Technological Activities Commission; Werner A. Baum, Membership Commission; and Glenn R. Hilst, Publications Commission; Commissioner Designate, Earl G. Droessler, Scientific and Technological Activities Commission; Executive Director Kenneth C. Spengler; and Secretary-Treasurer David F. Landrigan. Attending for a portion of the meeting was Ray D. Booker, Chairman of the Board of Professional Ethics. Also attending by special invitation from the Council were: Peter Hildebrand, University of Chicago; Richard Bennett, University of Toronto, and Margaret LeMone, National Center for Atmospheric Research.

Mr. Spengler attended the Eighth Conference on Severe Local Storms held in Denver, Colo., from 15-17 October. He continued on to Boulder, Colo., for the Symposium on Cumulus Modelling on the 18th and 19th.

On 24 October Mr. Spengler was in Washington, D.C., to discuss matters related to the Meteorological and Geoastrophysical AbStracts. He also attended a public ceremony in which a report prepared by the American Chemical Society was presented in the chambers of the Science and Astronautics Committee of the House of Representatives. The report, entitled "Chemistry in the Economy," outlined the accomplishments of chemistry in industry, surveyed the discipline's professional people, and attempted to measure its influence on the American economy.

On the evening of the 25th, Executive Director Spengler attended the annual reception and dinner of the Board of Trustees of the Mitre Corporation.

Visitors to AMS headquarters during October included: George Bulgarelli, Pittsfield, Mass.; C. H. Huang, Boston, Mass.; Carl A. Mazzola, North Reading, Mass.; Mrs. Hannah Boehme, Framingham, Mass.; John Young, Massachusetts Institute of Technology; Larry Goldman, Boston, Mass.; Eugenia Kálnay de Rivas, Massachusetts Institute of Technology; Jule Charney, Massachusetts Institute of Technology; N. A. Lieurance, McLean, Va.; Garrett D. Byrnes, Providence, R. I.; Ginger and Richard Stobbe, Harrisburg, Pa.; Michael Pometta, San Francisco, Calif.; Barry Pryor, Boston, Mass.; Jack Kerrigan, Boston, Mass.; and Carl Depaul, Newton, Mass. 


\section{ELECTRIC CHART DRIVES}

- Three output shafts and appropriate time-scale gearing (pinion and gear) provide all chart periods previously available plus one of 35.9 days/rev of chart cylinder.

- 31-day charts are available for hygrothermographs, thermographs, microbarographs, rain gage, and water-stage recorders.

- The Chart Drives are interchangeable with Belfort and Friez spring-powered drives.

- A timing accuracy including a chart of $5 \mathrm{sec} / \mathrm{hr}$ but no greater than $14 \mathrm{~min} / \mathrm{wk}$.

- A battery life up to 4 months over a temperature range of -40 to $+125 \mathrm{~F}$. with one alkaline-manganese dioxide C-cell.

Chart Drive complete with

cylinder and time-scale

gearing but $w / 0$ battery

$\$ 90.00$

Send for free bulletin $73-33$

\section{BELFORT INSTRUMENT COMPANY}

1600 S. CLINTON STREET

BALTIMORE, MARYLAND 21224 U.S.A. 